J. Clin. Chem. Clin. Biochem.

Vol. 25, 1987, pp. 795-798

(C) 1987 Walter de Gruyter \& Co.

Berlin - New York

\title{
A Nomogram for the Interpretation of Acid-Base Data
}

\author{
By O. Müller-Plathe \\ Allgemeines Krankenhaus Altona, Zentrallabor
}

(Received May 4, 1987)

Summary: A diagnostic nomogram based on $\log p \mathrm{CO}_{2}$ and $\log c \mathrm{HCO}_{3}^{-}$as coordinates is presented. The significance areas for compensated acid-base disorders are indicated. The nomogram facilitates the recognition of mixed acid-base disorders. The graph is being used for on-line plotting.

\section{Introduction}

Print-outs of modern blood gas analysers are becoming increasingly complicated. This does not facilitate the interpretation of acid-base data for the clinician, as the single data of the acid-base status cannot be interpreted without consideration of the other results. In this situation, characterized by highly complex data, the clinical chemical laboratory has the duty not only to provide accurate figures, but also to present the findings in a form that is understandable by the clinician.

\section{Description and Use of the Nomogram}

\section{Coordinates}

On the abscissa $p \mathrm{CO}_{2}$ and on the ordinate $c \mathrm{HCO}_{3}^{-}$ are indicated logarithmically. This arrangement enables the presentation of $\mathrm{pH}$ as a system of strictly parallel straight lines which are calculated with the following trañsformation of the Henderson-Hasselbalch equation:

$$
\begin{aligned}
& c \mathrm{HCO}_{3}^{-}(\mathrm{mmol} / \mathrm{l})= \\
& 0.0307 p \mathrm{CO}_{2}(\mathrm{mmHg}) \cdot 10^{(\mathrm{pH}-6.105)} \\
& \text { corresponding to } \\
& c \mathrm{HCO}_{3}^{-}(\mathrm{mmol} / \mathrm{l})=0.230 p \mathrm{CO}_{2}(\mathrm{kPa}) \cdot 10^{(\mathrm{pH}-6.105)}
\end{aligned}
$$

With the ranges chosen, $p \mathrm{CO}_{2}$ from 10 to $100 \mathrm{mmHg}$ $(1.3-13.0 \mathrm{kPa})$ and $c \mathrm{HCO}_{3}^{-}$from 6 to $60 \mathrm{mmol} / \mathrm{l}$, the pH 7.4 isopleth almost exactly forms the diagonal of the graph.

\section{Areas}

The oval area around $p \mathrm{CO}_{2}=40 \mathrm{mmHg}$ and $c \mathrm{HCO}_{3}^{-}=24 \mathrm{mmol} / 1$ marks the reference range for males and females $(1,2)$. The limits of the six significance areas for the acid-base disturbances were calculated and drawn according to data from the literature and our own observations. Each area is based on experimental or clinical investigations and approximately represents the 95 percent area.

The following publications were taken into account for the significance areas:

Acute respiratory acidosis and alkalosis:

Arbus, G. S. et al. (3)

Brackett, N. C. et al. (4)

Siggaard-Andersen, $O$. (5)

Chronic respiratory acidosis and alkalosis:

Brackett, N. C. et al. (6)

Müller-Plathe et al. (7)

Siggaard-Anderson, $O$. (5)

Metabolic acidosis and alkalosis:

Albert, M. S. et al. (8)

Kildeberg, P. (9)

Siggaard-Andersen, $O$. (5)

Table 1 demonstrates the calculation of the significance area for chronic respiratory acidosis as an example for this procedure. 
Tab. 1. Establishment of the significance area for chronic respiratory acidosis.

\begin{tabular}{|c|c|c|c|c|}
\hline \multirow{2}{*}{$\begin{array}{l}\text { Refer- } \\
\text { ence }\end{array}$} & \multicolumn{2}{|l|}{$p \mathrm{CO}_{2}$} & \multicolumn{2}{|c|}{$\mathrm{cHCO}_{3}^{-}(\mathrm{mmol} / \mathrm{l})$} \\
\hline & $\mathrm{mmHg}$ & $\mathrm{kPa}$ & $\begin{array}{l}\text { values } \\
\text { from } 1 . c .\end{array}$ & $\begin{array}{l}\text { limits in } \\
\text { the present } \\
\text { nomogram }\end{array}$ \\
\hline $\begin{array}{l}6 \\
7 \\
5\end{array}$ & $\begin{array}{l}50.0 \\
48.0-50.9 \\
50.0\end{array}$ & $\begin{array}{l}6.7 \\
6.4-6.8 \\
6.7\end{array}$ & $\begin{array}{l}26.8-35.3 \\
23.7-32.7 \\
26.4-31.7\end{array}$ & -33.2 \\
\hline $\begin{array}{l}6 \\
7 \\
5\end{array}$ & $\begin{array}{l}60.0 \\
60.0-62.9 \\
60.0\end{array}$ & $\begin{array}{l}8.0 \\
8.0-8.4 \\
8.0\end{array}$ & $\begin{array}{l}30.7-39.5 \\
29.4-38.2 \\
30.2-35.5\end{array}$ & $30.1-37.7$ \\
\hline $\begin{array}{l}6 \\
7 \\
5\end{array}$ & $\begin{array}{l}70.0 \\
67.0-75.9 \\
70.0\end{array}$ & $\begin{array}{l}9.3 \\
8.9-10.1 \\
9.3\end{array}$ & $\begin{array}{l}33.4-44.0 \\
33.5-44.9 \\
33.3-38.7\end{array}$ & $33.4-42.5$ \\
\hline $\begin{array}{l}6 \\
7 \\
5\end{array}$ & $\begin{array}{l}80.0 \\
76.0-84.9 \\
80.0\end{array}$ & $\begin{array}{l}10.7 \\
10.1-11.3 \\
10.7\end{array}$ & $\begin{array}{l}36.5-47.0 \\
34.6-47.8 \\
35.9-40.8\end{array}$ & $35.7-45.2$ \\
\hline 7 & $85.0-95.0$ & $11.3-12.7$ & $38.2-49.8$ & $38.0-47.0$ \\
\hline $\begin{array}{l}6 \\
7 \\
5\end{array}$ & $\begin{array}{l}100.0 \\
104.0 \\
100.0\end{array}$ & $\begin{array}{l}13.3 \\
13.9 \\
10.3\end{array}$ & $\begin{array}{l}41.6-53.5 \\
42.3-53.3 \\
38.2-43.9\end{array}$ & $39.0-48.7$ \\
\hline
\end{tabular}

\section{Directions for use}

Enter the results for $p \mathrm{CO}_{2}$ (abscissa) and $c \mathrm{HCO}_{3}^{-}$ (ordinate) and find the status mark, which may be located

- In the normal area:

No acid-base abnormality present.

- In one of the six shaded areas:

Status typical for the indicated "pure" disturbance with a normal degree of compensation.

- In one of the free parts of the graph between the shaded areas:

Status typical for the indicated "mixed" disturbance.

\section{Alternative use}

One of the quantities indicated on the coordinates may be replaced by $\mathrm{pH}$ if this is preferred for any reason. $\mathrm{pH}$ values, too, can be entered precisely because of the parallelity of the $\mathrm{pH}$ isopleths.

\section{Discussion}

A nomogram for the interpretation of acid-base data should fulfill the following requirements

- easily understandable

- universally applicable

- suitable for on-line plotting
Numerous acid-base nomograms with different combinations of coordinates have been designed in the past $(10-15)$, preferably for the calculation of derived quantities. From some of these graphs interpretational nomograms were developed. The Siggaard-Andersen "acid-base chart" (5) with the coordinates $\mathrm{pH}$ and $\log p \mathrm{CO}_{2}$ is highily suitable for diagnostic and therapeutic interpretations. But it is strictly directed to the base excess concept, and plasma bicarbonate which is preferred by many clinicians can only be entered or read indirectly. The Arbus diagram (16) with the coordinates $p \mathrm{CO}_{2}$ and $c \mathrm{HCO}_{3}^{-}$has the disadvantage of non-parallel $\mathrm{pH}$ isopleths. The nomogram of Cogan et al. (17) with $\mathrm{pH}$ and $c \mathrm{HCO}_{3}^{-}$as coordinates shows a bundle of curved non-parallel $p \mathrm{CO}_{2}$ lines hindering exact reading of this important quantity.

\section{Remarks on the present nomogram}

The acid-base equilibrium as expressed in terms of the carbonic acid-bicarbonate system is determined by $p \mathrm{CO}_{2}$ (abscissa in the present nomogram) and $c \mathrm{HCO}_{3}^{-}$(ordinate in the present nomogram). The result of the two determinants is pH. Status marks superior to and left of the emphasized diagonal $\mathrm{pH}$ $=7.4$ ) indicate an alkalotic tendency, while marks inferior to and right of this line indicate an acidotic tendency.

The areas for metabolic acidosis and.alkalosis refer to disorders with a duration of at least $24 \mathrm{~h}$, allowing the respiratory centre to respond. If the status mark is beyond these areas it is necessary to exclude or to verify an additional respiratory dysfunction. Concerning metabolic alkalosis it should be mentioned that some authors $(9,16)$ assume a greater variation in compensatory $\mathrm{CO}_{2}$ retention than can be read from the present graph.

The areas for acute respiratory disturbances, naturally, show a strong deviation. from the $\mathrm{pH} 7.4$ line because they are predominantly compensated by blood buffer reactions. After 5 to 7 days the renal compensation for hypo- or hypercapnia is completed. Only at this stage can a status mark inside the areas for chronic respiratory acidosis or alkalosis be expected. A status mark situated between the acute and chronic respiratory areas or even remaining inside the field for the acute disorder means that either renal function is impaired by disease or drugs or that the time interval for the tubular rësponse was too short.

There are two areas which are indicated for a combination of counteracting disturbances. Those constellations with a $\mathrm{pH}$ close to $7.4 \mathrm{mimic}$ "overcompensa- 


\section{ACID BASE DIAGNOSTIC NOMOGRAM (0.Müller-Plathe, 1987)}

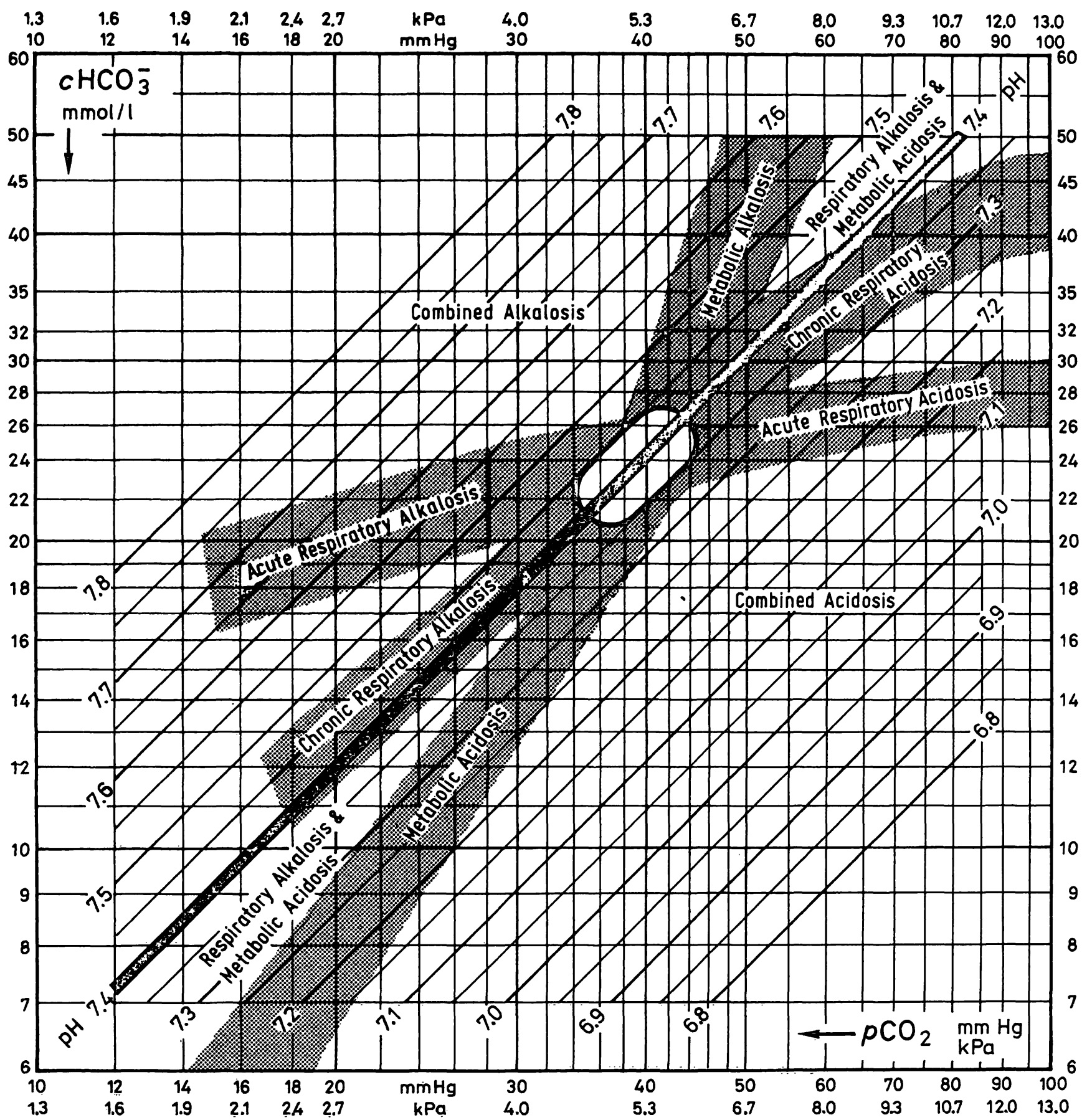

Fig. 1. The acid-base diagnostic nomogram.

tion", a term which should be avoided. A combination of respiratory alkalosis and metabolic acidosis may be caused by hyperventilation with subsequent lactic acidosis. Respiratory acidosis and metabolic alkalosis are frequently encountered together, e.g. in obstructive emphysema with cardiac failure and diuretic therapy. Residual hyperbicarbonataemia after rapid improvement of severe hypercapnia is another example.
Combined acidosis or alkalosis leads to very high $\mathrm{pH}$ deviations, because respiratory and metabolic causes influence $\mathrm{pH}$ in the same direction. Examples: Mixed acidosis by cardiac arrest with acute hypercapnia and hypoxic lactacidosis; combined alkalosis in patients with artificial respiration and additional drug therapy (corticoids, diuretics). The term non-compensated acidosis or alkalosis is used for combined acid-base disorders, if one of the two disturbances is regarded 
as predominant. But in these cases, too, at least two impairments are present. Thus, "non-compensation" represents a graded difference, at best.

\section{Conclusion}

This paper does not contain new data! Clinical and experimental data mainly from the sixties have been re-evaluated. An attempt has been made to present these data in an easily understandable diagram to facilitate the recognition of pure ("compensated") and mixed acid-base disorders, mainly for those who consider $\mathrm{CHCO}_{3}^{-}$as the most relevant base quantity. The nomogram proves to be very helpful. Therefore, on-line plotting from a Corning 178 blood gas analyser was started*.

\section{Acknowledgement}

* We are indebted to Ciba-Corning Diagnostics GmbH, D-6301 Fernwald 2, Federal Republic of Germany, who developed a computer program for on-line plotting on this nomo= gram which runs on a HP85 calculator.

\section{References}

1. Siggaard-Andersen, O. (1974) The acid-base status of the blood, Munksgaard, Copenhagen.

2. Müller-Plathe, O. (1982) Säure-Basen-Haushalt und Blutgase, Thieme, Stuttgart-New York.

3. Arbus, G. S., Hebert, M. D., Levesque, P. R., Etsten, B. E. \& Schwartz, W. B. (1969) New Engl. J. Med. 280, 117123.

4. Brackett, N.' C., Cohen, J. J. \& Schwartz, W. B. (1965) New Engl. J. Med. 272, 5-12.

5. Siggaard-Andersen, O. (1971) Scand. J. Clin. Lab. Invest. $27,239-245$.

6. Brackett, N. C., Wingo, C. F., Muren, O. \& Solano, J. T. (1969) New Engl. J. Med. 280, 124-130.

7. Müller-Plathe, O. \& Meinekat, E. (1966) Dtsch. Med. Wochenschr. 91, 2284-2289.

8. Albert, M. S., Dell, R. B. \& Winters, R. W. (1967) Ann. Intern. Med. 66, 312-322.

9. Kildeberg, P. (1963) Acta Med. Scand. 174, 515- 522.

10. Singer, R. B. \& Hastings, A. B. (1948) Medicine (Baltimore) $27,223 \div 242$.

11. Davenport, H. W. (1958) The ABC of acid-base chemistry, The University of Chicago Press.

12. Siggaard-Andersen, O. (1962) Scand. J. Clin. Lab. Invest. $14,598-604$.

13. Siggaard-Andersen, O. (1963) Scand. J. Clin. Lab. Invest. $15,211-217$.

14. Thews, G. (1967) Pflügers Arch. Ges. P̀hysiol. 296, 212214.

15. Thews, G. (1971) Nomogramme zum Säure-Basen-Status des Blutes und zum Atemgastransport, Springer, Heidelberg-New York.

16. Arbus, G. S. (1973) Canad. Med. Ass. J. 109, 291-292.

17. Cogan, M. G., Rector, F. C. \& Seldin, D. W. (1981) Acidbase disorders. In: The Kidney (Brenner, B. M. \& Rector, F. C., eds.) Saunders, Philadelphia.

Prof. Dr. O. Müller-Plathe

Allgemeines Krankenhaus Altona

Paul-Ehrlich-Str. 1

2000 Hamburg 50 